\title{
Persepsi tokoh masyarakat dan peternak terhadap kinerja penyuluh dalam meningkatkan usaha peternakan sapi potong di Kecamatan Sangkub Kabupaten Bolaang Mongondow Utara
}

\author{
H. Umar, J Lainawa*, G. D. Lenzun, Z. M. Warow. \\ Fakultas Peternakan Universitas Sam Ratulangi Manado 95115 \\ *Korespondensi (corresponding author): joli@gmail.com
}

\begin{abstract}
ABSRTAK
Penelitian ini adalah penelitian deskriptif yaitu untuk melihat persepsi tokoh masyarakat dan peternak terhadap kinerja penyuluh. Pemilihan sampel responden ditentukan secara sengaja (Purposive) yaitu aparat desa, tokoh masyarakat dan peternak di desa Sangkub 1, Tombolango, Busisingo, Pangkusa dan Sidodadi, sebanyak 30 responden. Pengukuran variabel dilakukan dengan mengikuti pedoman "Skala Likert" dengan memberi skor pada setiap jawaban responden. Hasil penelitian menunjukkan bahwa persepsi tokoh masyarakat terhadap kinerja penyuluh dalam meningkatkan usaha peternakan sapi potong di Kecamatan Sangkub Kabupaten Bolmong Utara, pada aspek penyuluh sebagai penghubung 100\% responden menilai bermanfaat, aspek materi penyuluhan $93 \%$ responden menilai bermanfaat dan $7 \%$ responden ragu-ragu, aspek metode penyuluhan $63 \%$ responden menilai bermanfaat dan $37 \%$ responden menilai ragu-ragu, aspek alat bantu penyuluhan $100 \%$ responden menilai tidak bermanfaat, aspek sasaran penyuluhan $93 \%$ responden menilai bermanfaat dan $3 \%$ responden ragu-ragu, aspek waktu dan tempat penyuluhan $100 \%$ responden menilai bermanfaat, serta aspek peningkatan usaha peternakan sapi potong 100\% responden menilai bermaanfaat. Berdasarkan hasil analisa hubungan persepsi tokoh masyarakat dan peternak terhadap kinerja penyuluh dalam peningkatan usaha peternakan sapi potong dengan model "rank spearman" diperoleh hubungan nyata antara persepsi tokoh masyarakat dan aparat desa terhadap kinerja penyuluh dalam peningkatan usaha ternak sapi potong.
\end{abstract}

Kata Kunci: Persepsi, kinerja penyuluh, kinerja penyuluh, sapi potong

\begin{abstract}
ABSRTACT
PERCEPTION OF COMMUNITY LEADERS AND FARMERS TOWARDS THE PERFORMANCE OF EXTENSION WORKERS IN IMPROVING BEEF CATTLE FARMING BUSINESS IN SANGKUB DISTRICT NORTH BOLAANG MONGONSOW This research was a descriptive research that is aim to know the perception of community leaders and breeders on the performance of extension workers. The selection of sample respondents was determined deliberately (Purposive) namely village officials, community leaders and farmers in the villages of Sangkub 1, Tombolango, Busisingo, Pangkusa and Sidodadi, as many as 30 respondents. Variable measurement is done by following the guidelines "Likert Scale" with member score on each respondent's answer. The results showed that the perception of community leaders on the performance of extension workers in improving the business of beef cattle farming in Sangkub District, North Bolmong Regency, in the extension aspect as a communicator $100 \%$ of respondents rated it useful, the material aspect of counseling $93 \%$ of respondents rated it useful and $7 \%$ of respondents were
\end{abstract}


hesitant, aspects of counseling methods $63 \%$ of respondents rated it useful and $37 \%$ of respondents rated it as doubtful, aspects of counseling aids $100 \%$ respondents considered it un useful, aspects of the counseling target $93 \%$ of respondents rated it useful and 3\% of respondents were hesitant, the time and place aspects of counseling $100 \%$ of respondents rated it useful, as well as aspects of increasing the beef cattle farming business $100 \%$ of respondents rated the benefits. Based on the results of analysis of the relationship of perception of community leaders and breeders to the performance of extension workers in improving the business of beef cattle farming with the model "rank spearman" showed that there was a significant correlation between the perception of community leaders and village officials to the performance of extension workers in improving the business of beef cattle.

Keywords: Perceptions, breeders, performance of extension workers, beef cattle

\section{PENDAHULUAN}

Penyuluhan pertanian, perikanan, dan kehutanan merupakan proses pembelajaran bagi pelaku utama agar mereka mau dan mampu menolong dan mengorganisasikan dirinya dalam mengakses informasi pasar, teknologi, permodalan, dan sumber daya lainnya, sebagai upaya untuk meningkatkan produktivitas, efisiensi usaha, pendapatan, dan kesejahteraannya, serta meningkatkan kesadaran dalam pelestarian fungsi lingkungan hidup.

Berdasarkan Undang-Undang Nomor 16 tahun 2006, Kelembagaan penyuluhan terdiri atas; kelembagaan penyuluhan pemerintah, kelembagaan penyuluhan swasta; dan kelembagaan penyuluhan swadaya.

Berdasarkan hasil penelitian terdahulu yang dilakukan Talibo et al. (2017), bahwa persepsi petani peternak sapi potong terhadap peran penyuluh di kecamatan Sangkub kabupaten Bolaang Mongondow Utara jika ditinjau dari aspek peran penyuluh sebagai fasilitator, $96,67 \%$ menilai baik dan 3,33\% menilai sangat baik. Peran penyuluh sebagai mediator, 83,33\% menilai cukup baik dan 3,33\% menilai baik. Peran penyuluh sebagai motivator, $83,33 \%$ menilai baik dan $16,67 \%$ menilai sangat baik. Peran penyuluh sebagai edukator, 93,33\% menilai baik dan $6,67 \%$ menilai sangat baik. Peran penyuluh sebagai komunikator, $100 \%$ petani peternak menilai baik. Sehingga secara keseluruhan Talibo (2017) menyimpulkan bahwa persepsi petani peternak terhadap peran penyuluh di kecamatan Sangkub kabupaten Bolaang Mongondow Utara menunjukkan bahwa 93,33\% petani peternak menilai baik dan $6,67 \%$ menilai sangat baik.

Namun dalam penelitian itu responden yang digunakan Talibo et al. (2017) lebih terfokus kepada petani, dimana pemilihan sampel diarahkan kepada kelompok tani ternak Keong Mas di desa Tombolango, kelompok tani ternak Motumping Mandiri di desa Busisingo Induk, dan kelompok tani ternak Kwi Bersehati di desa Sangkub II yang juga memiliki masing-masing 10 anggota petani peternak. Pemilihan responden dilakukan dengan mengambil seluruh petani peternak pada sampel kelompok terpilih yang berjumlah 30 orang. Padahal dalam menentukan manfaat dari hasil penyuluhan pengembangan usaha peternakan sapi potong, keterlibatan pemerintah desa dan para tokoh masyarakat sangat dibutuhkan dalam hal berkontribusi memberikan penilaian terhadap eksistensi lembaga penyuluhan bagi pengembangan usaha peternakan sapi potong di Kecamatan Sangkub. Karena itu dalam penelitian ini pemerintah desa dan para tokoh masyarakat dijadikan sebagai sasaran penelitian untuk mendapatkan informasi bagi eksistensi lembaga penyuluhan yang terkait dengan 
bagaimana peran penyuluh dan Instansi terkait dalam perannnya memberikan penyuluhan terhadap pengembangan usaha peternakan sapi potong di Kecamatan Sangkup Kabupaten Bolaang Mongondow Utara (Bolmut).

\section{METODE PENELITIAN}

\section{Objek penelitian}

Objek dalam penelitian ini adalah tokoh masyarakat dan peternak di Kecamatan Sangkup Kabupaten Bolaang Mongondow Utara, dalam hal memberikan penilaian terhadap kinerja penyuluh dan Instansi terkait pada kegiatan penyuluhan yang dilakukan terhadap petani (kelompok tani) ternak sapi potong.

\section{Metode penelitian.}

Metode penelitian yang dilakukan dalam penelitian ini adalah survey, dimana hal ini dimaksudkan sebagai suatu penelitian dengan cara menghimpun informasi dari sampel yang diperoleh dari suatu populasi, dengan tujuan untuk melakukan generalisasi sejauh populasi dari mana sampel tersebut diambil (Paturochman, 2012). Tujuan survei adalah untuk mengumpulkan sejumlah data melalui alat pengukur wawancara.

Untuk metode survei, informasi dikumpulkan dari responden dengan menggunakan kuesioner. Pada penelitian survei yang diakan dilakukan ini, penggunaan kuesioner merupakan hal yang pokok untuk pengumpulan data. Hasil kuesioner tersebut akan terjelma dalam angka-angka, tabel-tabel, analisa statistik dan uraian serta kesimpulan penelitian. Kuesioner bersifat efisien sehingga cocok digunakan bila jumlah respon den cukup besar dan tersebar diwilayah yang luas. Penelitian ini menggunakan metode deskriptif dengan fokus analisis pada data angka (numerical) untuk mengukur respon para respsponden terhadap kegiatan penyuluhan yang dilakukan kepada petani (kelompok ternak). Sondakh et al. (2019), metode deskriptif, yaitu suatu metode atau cara menganalisis dan menguraikan data penelitian yang ada, dan dikaitkan dengan teori-teori yang ada.

\section{Penentuan daerah penelitian}

Penelitian dilaksanakan di Desa Sangkup I, Tombolango, Busisingo, Pangkusa dan Sidodadi dalam wilayah Kecamatan Sangkub Kabupaten Bolaang Mongondow Utara. Lokasi tersebut dipilih secara sengaja (purposive) dengan pertimbangan sebagai berikut:

1. Merupakan desa yang tingkat kepemilikan ternak lebih banyak dari desa lainnya (BPS Sangkub Dalam Angka 2019).

2. Pernah dan sering mendapat penyuluhan dari penyuluh, dimana saat dilakukan penyuluhan aparat desa dan tokoh masyarakat diundang hadir sehingga dinyatakan sebagai responden yang mengerti persis kegiatan penyuluhan yang dilakukan.

\section{Teknik penentuan responden}

Teknik penentuan responden dalam penelitian ini adalah purposive sampling, dimana teknik ini merupakan pengambilan sampel yang dilakukan dengan sengaja dengan memilih sampel yang dianggap tau persis terhadap permasalahan penelitian, yaitu Kepala Desa 5 orang, Tokoh Agama 10 orang, Tokoh Masyarakat 5 orang. Selain itu sebagai pembanding ditambah 10 orang peternak yang sedang memelihara ternak sapi potong serta pernah mengikuti penyuluhan.

\section{Teknik pengumpulan data}

Pengumpulan data dilakukan dengan mengumpulkan data primer dan sekunder. Data primer dalam penelitian ini didapat dari responden dengan menggunakan kuesioner yang telah disusun untuk mendapatkan informasi yang dibutuhkan sedangkan data sekunder diambil dari dokumen-dokumen yang 
menunjang kebutuhan dalam pelaksanaan penelitian ini yaitu dari Kantor Desa dan Instansi Terkait serta dari berbagai terbitan internet yang menunjangnya.

\section{Operasionalisasi variabel dan dimensi yang diteliti}

Operasional variabel merupakan penjelasan dari masing-masing variabel yang digunakan dalam penelitian terhadap indikator-indikator yang membentuknya. Pada penelitian ini, yang menjadi variabel adalah penyuluh dan kegiatan penyuluhan yang telah dilakukan penyuluh kepada peternak. Adapun dimensi dalam kegiatan penyuluhan ini adalah:

1). Penyuluh sebagai penghubung atau saluran atau jembatan antara lembaga penelitian dengan petani,

2) Materi penyuluhan merupakan segala sesuatu yang disampaikan dalam proses komunikasi yang menyangkut ilmu dan teknologi atau isi yang terkandung dalam setiap pelaksanaan kegiatan penyuluhan,

3) Metode penyuluhan adalah prosedur yang digunakan dalam kegiatan penyuluhan,

4) Alat bantu penyuluhan yang berfungsi sebagai perantara yang menghubungkan penyuluh dengan peternak sebagai alat melakukan komunikasi,

5) Sasaran penyuluhan adalah siapa sebenarnya yang disuluh atau ditujukan kepada siapa penyuluhan,

6) Waktu dan tempat penyuluhan merupakan faktor yang penting, maka perlu diperhitungkan waktu dan lamanya serta lokasi diadakannya penyuluhan agar informasi dapat tersampaikan,

Penilaian terhadap penyuluh diukur menggunakan skala Likert, dengan menggunakan tiga kategori yaitu: Bermanfaat diberi skor 3, ragu-ragu diberi skor 2, tidak bermanfaat diberi skor 1 .

Budiaji (2013), skala likert adalah skala pengukuran yang dikembangkan oleh Likert tahun 1932. Skala likert mempunyai empat atau lebih butir-butir pertanyaan yang dikombinasikan sehingga membentuk sebuah skor/nilai yang merepresentasikan sifat individu, misalkan pengetahuan, sikap, dan perilaku.

Untuk menguji hubungan antara persepsi aparat pemerintah desa dan tokoh masyarakat terhadap kinerja penyuluh meningkatkan usaha peternak sapi potong di Kecamatan Sangkub dihubungkan dalam bentuk skala ordinal, maka digunakan analisis korelasi Rank Spearman (rs). Menurut Sugiyono dalam Prasetyo et al. (2013), Korelasi Rank Spearman digunakan untuk mencari signifikansi hipotesis asosiatif bila masing-masing variabel yang dihubungkan berbentuk ordinal, dan sumber data antar variabel tidak harus sama. Korelasi Rank Spearman dihitung dengan rumus:

$$
r s=1 \frac{6 \Sigma d^{2}}{n\left(n^{2}-1\right)}
$$

Keterangan:

$\mathrm{r}_{\mathrm{s}}=$ Nilai korelasi jenjang sperman

$\boldsymbol{\Sigma} \mathrm{d}^{2}=$ total kuadrat selisih antar ranking

$\mathrm{N}=$ jumlah sampel penelitian.

Uji kriteria:

1. Jika nilai signifikansi $<0,05$ maka penyuluh berhubungan dalam meningkatkan usaha peternakan sapi potong.

2. Jika nilai signifikansi $>0,05$ maka peran penyuluh tidak berhubungan dalam meningkatkan usaha peternakan sapi potong.

\section{HASIL DAN PEMBAHASAN}

\section{Deskripsi umum lokasi penelitian letak dan luas wilayah.}

Secara luas wilayah, Kecamatan Sangkub memiliki wilayah seluas 567,85 $\mathrm{km} 2$ atau 30,58 persen dari luas wilayah Kabupaten Bolaang Mongondow Utara yang juga merupakan wilayah kecamatan terluas yang ada di Kabupaten Bolaang Mongondow Utara. 


\section{Persepsi tokoh masyarakat dan peternak terhadap kinerja penyuluh.}

Penyuluh diharuskan membuat perencanaan tentang beberapa hal yang dapat membantu peternak dalam meningkatkan usaha peternakan sapi potong, mengambil keputusan yang efektif serta dapat meningkatkan produktivitas kelompok peternak sapi yang ada di Kecamatan Sangkub Kabupaten Bolaang Mongondow Utara.

Sumardjo (2010) menyatakan tingkat kompetensi penyuluh masih relative rendah. Hal tersebut sejalan dengan penelitian Sucihatiningsih dan Waridin (2010); Anantanyu (2011); Seran et al. (2011); Prawiranegara et al. (2015) menemukan bahwa kapasitas penyuluh dan kapasitas kelembagaanya kurang memadai sehingga perlu ditingkatkan, karena kinerja penyuluhan rendah, serta kapasitas penyuluh lapangan rendah dan perlu ditingkatkan oleh pihak-pihak pemangku kepentingan. Kegiatan penyuluhan merupakan salah satu upaya untuk meningkatkan kapasitas petani. Hal tersebut, menuntut penyuluh untuk mampu meningkatkan kapasitas dirinya agar dapat melaksanakan berbagai peran dengan baik, sehingga perlu dilakukan penelitian ini untuk melihat peningkatan kinerja penyuluh berperan terhadap peningkatan ternak sapi potong.

Adapun variabel yang dapat dijadikan pengukuran peranan penyuluh di Kecamatan Sangkub Kabupaten Bolaang Mongondow Utara adalah, penyuluh sebagai penghubung, kemampuan menjelaskan materi, metode penyuluhan, alat bantu penyuluh, sasaran penyuluh, waktu dan tempat penyuluh.

\section{Penyuluh sebagai penghubung}

Penyuluh sebagai penghubung atau saluran atau jembatan antara lembaga penelitian dengan peternak. Menurut Sundari et al. (2015), penyuluh sebagai penghubung menyampaikan aspirasi petani dan peneliti yaitu senantiasa membawa inovasi baru hasil-hasil penelitian untuk dapat memajukan usaha tani.

Hasil pengamatan penyuluh sebagai penghubung menurut persepsi responden dapat dilihat pada tabel 1 .

Berdasarkan tabel 1, yang dilakukan dengan perhitungan skala likert, seluruh responden menyatakan merasakan manfaat penyuluh dalam kinerjanya sebagai penghubung menyampaikan berbagai ilmu pengetahuan dan teknologi peternakan sapi potong sebagai implementasi hasil penelitian dari lembaga penelitian kepada responden. Hal ini berarti seluruh responden merasakan manfaat dari ilmu pengetahuan dan teknologi yang disampaikan penyuluh yang ditindak lanjuti dengan pernyataan responden untuk mengembangkan usaha peternakan sapi potong.

\section{Materi penyuluhan}

Materi penyuluhan merupakan segala sesuatu yang disampaikan dalam proses komunikasi yang menyangkut ilmu dan teknologi atau isi yang dikandung dalam setiap pelaksanaan kegiatan penyuluhan.

Tabel 1. Penyuluh sebagai penghubung atau saluran atau jembatan antara lembaga penelitian dan peternak.

\begin{tabular}{cccc}
\hline Penilaian & Skor & Jumlah Responden & Persentase \\
\hline Bermanfaat & $7-9$ & 30 & $100 \%$ \\
Ragu-ragu & $4-6$ & 0 & $0 \%$ \\
Tidak Bermanfaat & $1-3$ & 0 & $0 \%$ \\
\hline
\end{tabular}


Tabel 2. Materi Penyuluhan.

\begin{tabular}{cccc}
\hline Penilaian & Skor & Jumlah Responden & Persentase \\
\hline Bermanfaat & $5-6$ & 28 & $93 \%$ \\
Ragu-ragu & $3-4$ & 2 & $7 \%$ \\
Tidak Bermanfaat & $1-2$ & 0 & $0 \%$ \\
\hline
\end{tabular}

Berdasarkan UU RI No. 16 Tahun

2006, Bab I Pasal 1 ayat 22, bahwa materi penyuluhan yang disampaikan oleh para penyuluh kepada pelaku utama dan dan pelaku usaha dalam berbagai bentuk yang meliputi informasi, teknologi, rekayasa sosial, manajemen, ekonomi, hukum, dan kelestarian lingkungan (Ahmad, 2017).

Hasil tabel 2 meunjukan 28 orang beranggapan atau berpandangan bahwa materi penyuluh yang telah disampaikan dalam kegiatan penyuluhan, bermanfaat bagi mereka (responden), meskipun ada 2 responden yang ragu-ragu. Hal ini menjelaskan bahwa responden merasa mengerti dan memahami dengan jelas materi yang disajikan oleh penyuluh.

\section{Metode penyuluhan}

Metode penyuluhan adalah prosedur yang digunakan dalam kegiatan penyuluhan. Metode penyuluhan sangatlah penting sehingga perlu dilakukan penelitian apakah metode penyuluhan yang dilakukan penyuluh di Kecamatan Sangkub sudah tepat dengan harapan peternak.

Berdasarkan hasil Tabel 3 dapat dilihat 19 orang memiliki anggapan atau pandangan bahwa prosedur yang digunakan penyuluh dalam kegiatan penyuluhan bermanfaat bagi pelaksanaan dan penerimaan responden, meskipun ada
11 responden yang persepsi ragu-ragu. Hal ini berarti sebagian besar mengangap bahwa metode penyuluhan yang dilakukan penyuluh di Kecamatan sangkub sudah berjalan berdasarkan prosedur. Hal ini juga sesuai dengan hasil penelitian Purnaningsih dalam Imran et al. (2019), yang menyatakan bahwa metode penyuluhan petanian sangat dirasakan manfaatnya bagi petani sehingga petani merasa memiliki banyak informasi dan pengetahuan yang didapat dari metode penyuluhan pertanian.

\section{Alat bantu penyuluhan}

Alat bantu penyuluhan berfungsi sebagai perantara yang menghubungkan penyuluh dengan peternak sebagai alat melakukan komunikasi. Alat bantu penyuluhan juga berperan penting dalam pelaksanaan penyuluhan. Persepsi tentang penggunaan alat bantu penyuluhan dapat dilihat pada Tabel 4.

Berdasarkan hasil penelitian yang dirangkum dalam Tabel 4, dapat dilihat bahwa seluruh responden yang berjumlah 30 orang menyatakan bahwa alat bantu yang digunakan dalam penyuluhan tidak bermafaat dalam fungsinya sebagai perantara yang menghubungkan penyuluh dengan peternak sebagai alat melakukan komunikasi.

Tabel 3. Metode Penyuluhan.

\begin{tabular}{cccc}
\hline Penilaian & Skor & Jumlah Responden & Persentase \\
\hline Bermanfaat & 3 & 19 & $63 \%$ \\
Ragu-ragu & 2 & 11 & $37 \%$ \\
Tidak Bermanfaat & 1 & 0 & $0 \%$ \\
\hline
\end{tabular}


Tabel 4. Alat Bantu Penyuluhan

\begin{tabular}{cccc}
\hline Penilaian & Skor & Jumlah Responden & Persentase \\
\hline Bermanfaat & 3 & 0 & $0 \%$ \\
Ragu-ragu & 2 & 0 & $0 \%$ \\
Tidak Bermanfaat & 1 & 30 & $100 \%$ \\
\hline
\end{tabular}

Artinya setiap penyuluhan yang dilakukan oleh penyuluh di Kecamatan Sangkub tidak pernah menggunakan alat penyuluh berupa slide, materi atau benda sebagai contoh.

\section{Sasaran Penyuluhan}

Sasaran penyuluhan adalah siapa sebenarnya yang disuluh atau ditujukan kepada siapa penyuluh dilakukan. Penilaian terhadap sasaran penyuluhan berdasarkan kehadiran peternak pada setiap penyuluhan dan keaktifan peternak bertanya/ menjawab/ berdiskusi ketika menghadiri penyuluhan, dapat dilihat pada Tabel 5.

Berdasarkan hasil pada Tabel 5, dapat dilihat 29 orang responden selalu terlibat dalam setiap penyuluhan, sedangkan 1 orang kadang-kadang untuk hadir atau aktif dalam setiap penyuluhan. Hal ini menjelaskan bahwa responden beranggapan kehadiran dalam penyuluhan sangat bermanfaat bagi mereka untuk meningkatkan usaha peternakan sapi potong.

\section{Waktu dan tempat penyuluhan}

Waktu dan tempat penyuluhan merupakan faktor penting, maka perlu diperhitungkan waktu dan lamanya, serta lokasi diadakannya penyuluhan agar informasi dapat

Berdasarkan hasil pada Tabel 6, 30 orang atau semua responden memiliki persepsi bahwa penggunaan waktu dan tempat penyuluhan bermanfaat untuk proses penyerapan pengetahuan. Bagi responden waktu yang tempat yang dipilih oleh penyuluh sudah sesuai dengan waktu dan tempat yang mereka harapakan ,sehingga proses penyuluhan bias berjalan dengan lancar.

\section{Peningkatan usaha peternakan sapi potong}

Peningkatan usaha peternakan sapi potong, berarti terjadi peningktan ternak serta berkurangnya tingkat kematian selama periode produksi dalam hal ini selama 1 tahun, dan terjadi perubahan perilaku dalam beternak.

Berdasarkan hasil Tabel 7, terlihat 30 orang mempunyai persepsi bahwa penyuluhan yang dilakukan penyuluh bermanfaat bagi peningkatan usaha.

Tabel 5. Sasaran Penyuluhan

\begin{tabular}{cccc}
\hline Penilaian & Skor & Jumlah Responden & Persentase \\
\hline Bermanfaat & 3 & 29 & $97 \%$ \\
Ragu-ragu & 2 & 1 & $3 \%$ \\
Tidak Bermanfaat & 1 & 0 & $0 \%$ \\
\hline
\end{tabular}


Tabel 6. Waktu dan Tempat Penyuluhan

\begin{tabular}{cccc}
\hline Penilaian & Skor & Jumlah Responden & Persentase \\
\hline Bermanfaat & 3 & 30 & $100 \%$ \\
Ragu-ragu & 2 & 0 & $0 \%$ \\
Tidak Bermanfaat & 1 & 0 & $0 \%$ \\
\hline
\end{tabular}

Tabel 7. Peningkatan Usaha Peternakan Sapi Potong

\begin{tabular}{cccc}
\hline Penilaian & Skor & Jumlah Responden & Persentase \\
\hline Bermanfaat & $7-9$ & 30 & $100 \%$ \\
Ragu-ragu & $4-6$ & 0 & $0 \%$ \\
Tidak Bermanfaat & $1-3$ & 0 & $0 \%$ \\
\hline
\end{tabular}

Tabel 8. Hasil Rank Spearman

\begin{tabular}{llrr}
\hline & & Kinerja Penyuluh & Peningkatan Usaha \\
\hline Peran Penyuluh & Correlation Coefficient & 1,000 &, 883 \\
& Sig. (2-tailed) & &, 004 \\
& $\mathrm{~N}$ & 30 & 30 \\
\hline Peningkatan usaha & Correlation Coefficient &, 883 & 1,000 \\
& Sig. (2-tailed) &, 004 & 30 \\
& $\mathrm{~N}$ & 30 & \\
\hline
\end{tabular}

Hal ini dibuktikan dengan adanya pertambahan jumlah populasi ternak serta perubahan system budi daya terutama penggunaan pakan ternak dan perawatan kesehatan ternak. Begitu juga pada system perkandangannya.

\section{Persepsi terhadap kinerja penyuluh terhadap peningkatan peternakan sapi potong}

Analisis data mengenai hubungan kinerja penyuluh dalam peningkatan usaha peternakan sapi potong di Kecamatan Sangkub digunakan uji korelasi spearman (rs), menggunakan spss 22.

Berdasarkan hasil output di tabel 8, diketahui nilai sig.(2-tailed) sebesar 0,004, karena nilai sig.(2-tailed) < dari 0,05 maka artinya ada hubungan yang signifikan antara kinerja penyuluh dalam meningkatkan usaha peternakan sapi potong di Kecamatan Sangkub.

Hal ini sejalan dengan penelitian sebelumnya Dali et al (2017), bahwa kinerja penyuluh pertanian lapangan (PPL) dan keberhasilan peternak sapi potong sebagian besar berada dalam kategori baik, sertaterdapat hubungan yang kuat antara kinerja PPL dengan keberhasilan peternak sapi potong.

\section{KESIMPULAN}

Persepsi tokoh masyarakat dan peternak, memiliki hubunbgan yang signifikan dengan kinerja penyuluh dalam peningkatan usaha sapi potong di Kabuapaten Bolaangmongondow Utara.

\section{DAFTAR PUSTAKA}

Ahmad A, 2017. Model penyuluhan partisipatif terhadap respon adopsi 
petani di Kabupaten Sinjai. Jurnal Agrominansia, 2 (1): 223 - 234.

Anantanyu S. 2011. Kelembagaan petani: peran dan strategi pengembangan kapasitasnya. Jurnal Sosial Ekonomi Pertanian dan Agribisnis (SEPA) 7(2): 102 - 109.

Badan Pusat Statistik Kabupaten Bolaang Mongondow Utara. 2019. Kecamatan Sangkub dalam Angka 2019.

Budiaji W. 2013. Skala pengukuran dan jumlah respon skala likert. Jurnal Ilmu Pertanian dan Perikanan, 2(2): 127-133.

Dali I., F.S. Oley, A.K. Rintjap dan J.M. Tumewu, 2017. Hubungan kinerja penyuluh pertanian lapangan dengan keberhasilan peternak sapi potong di Kecamatan Kwandang Kabupaten Gorontalo Utara. Jurnal Zootek, 37(2) : 403-414.

Imran A. N., Muhanniah dan B.R.W. Giono, 2019. Metode penyuluhan pertanian dalam meningkatkan pengetahuan dan keterampilan petani (studi kasus di Kecamatan Maros Baru Kabupaten Maros). Jurnal Agrisep, 18 (2): 289-304.

Paturochman.,M. 2012. Penentuan Jumlah dan Teknik Pengambilan Sampel. Unpad Press, Bandung. 55-56.

Prasetyo P.K, M. Harisudin dan E. Widiyanti, 2013. Persepsi Petani Terhadap Kemitraan Sayuran Dengan Asosiasi Aspakusa Makmur Kabupaten Boyolali. Skripsi Jurusan Agribisnis Fakultas Pertanian Universitas Sebelas Maret.

Prawiranegara D., Sumardjo, D.P. Lubis, dan S. Harijati. 2015. Strengthening role of farmer institution in enhance of innovation capability based on ict in west java province, Indonesia. International Journal of Humanities and Social Science, 5(12): 128-136.

Seran Y.L, M. Kote dan J. Triastono. 2011. Peningkatan kapasitas petani jagung melalui uji coba teknologi bersama petani dalam mendukung penguatan penyuluhan pertanian. Seminar Nasional Serelia: 675-683.

Sondakh R.D, F.S. Oley dan B.F.J. Sondakh, A.S. Sajow, 2019. Pengaruh penyuluh terhadap peternak sapi di Kecamatan Kowangkoan Barat. Zootec. 39 (2): 371-379.

Sucihatiningsih D.W.P dan Waridin. 2010. Model penguatan kapasitas kelembagaan penyuluh pertanian dalam meningkatkan kinerja usaha tani melalui transaction cost. Jurnal Ekonomi Pembangunan, 11(1): 1329.

Sumardjo. 2010. Penyuluhan Menuju Pengembangan Kapital Manusia dan Kapital Sosial dalam Mewujudkan Kesejahteraan Rakyat. Orasi Ilmiah Guru Besar Tetap Fakultas Ekologi Manusia.

Sundari, A.H., Yusra, dan Nurliza. 2015. Peran penyuluh pertanian terhadap peningkatan produksi usahatani di Kabupaten Pontianak. Jurnal Social Economic of Agriculture, 4 (1): 2631.

Talibo. R, B.F.J. Sondakh, A.S. Sajow, dan J. Lainawa, 2017. Analisis persepsi petani peternak sapi potong terhadap peran penyuluh di Kecamatan Sangkub Kabupaten Bolaang Mongondow Utara. Jurnal Zootec, 37(2): 513-525. 